\title{
Sustainable Global Supply Chain: A Systematic literature review:
}

\author{
Shaoor Ahmed \\ MS management IBA, Karachi
}

Nadia Sohail (Ph.D. Scholar)

\author{
International Islamic University Malaysia
}

\begin{abstract}
This study aims to summarize the literature on sustainable global supply chain management, so that researchers and practitioners can see the trends in the area at a single place. Systematic literature review (SLR) or Content analysis is used as a methodology of this literature review, studies that are published within time frame of 2010 to 2020 are included in this literature. Dimensions to analyze each article includes; year of publications, methodology of research, data collection type, unit of analysis, industry, country in which data is being collected, respondents' types, theory that is used in the study, dimensions of the sustainability and finally the purpose of study either it is to test the already existing theory or building up new theory. I found that sustainable global supply chain management is an emerging field and there is potential in area for researchers to explore the area.
\end{abstract}

Key Terms: Sustainability, Global supply chain management, SLR

\section{Introduction:}

Achieving a long-term competitive position and profit is essential for organizations, for this since past two decades incredible consideration is being paid to the manageability by firms (Carter \& Rogers, 2008)). Internal and external pressures to the firms majorly drive the awareness for sustainability such as the factors related to legislative and actions and pressures created by various stakeholders (Winter \& Knemeyer, 2013; Wolf, 2014). For organizations, sustainability is becoming a challenging issue on one hand as it requires paying attention along with economic to the social and environmental aspects by organizational behavior. On other hand, it is now seen as a strategic goal by global organizations (Closs et al., 2011; Donald S, 2009).

Sustainable development is defined as the possibilities of upcoming generations satisfying the needs of present ones by the world commission (1987) on environment and development. It mainly depends on two things, one is the decision-making process attentively and the other one is to create awareness for issues of collective importance (Golinelli \& Volpe, 2012). Alternatively, the idea is to construct the importance of environmental and social aspects in decision-making by the firms in their business activities.

The sustainability construct is multidimensional, widening the concept of the economic bottom line, it is emphasizing the use of resources efficiently and returns achieving on investment by considering and promoting the social responsibility of ecology (Elkington, 1997). According to Conception (2013), in today's business world company is not working on the island given a part of a wider network in the literature of relation management, it is important to act beyond the firm's boundaries. At present time the competitive positions have changed the structure of the competition and now competition among companies is changed to the competition of inter-supply chain (Christopher, 2005; Gold et al., 2010; Hult et al., 2007). 
Alternatively, an important factor for promoting sustainability is sustainable supply chain management (Esfahbodi et al., 2017; Tonelli et al., 2013). Sustainability itself is an important topic in the field of supply chain management and in decision-making, organizations are considering it for their long-term and shortterm goals (Esfahbodi et al., 2017; Haghighi et al., 2016). For improving the present and future of organizations it is important to integrate the sustainable developmental goals with the supply chain management (Ahi \& Searcy, 2013; Carter \& Rogers, 2008). Additionally, the rapid growth in competition, different demand patterns from the customer side, pressure from different stakeholders and government is encouraging companies to adopt the practices related to sustainable development on the supply chain (Gopal \& Thakkar, 2016). Comparatively, there is also an increasing trend worldwide in search of literature related to SSCM along with other relevant subjects (Tseng et al., 2019). Incredibly, by looking at the importance of sustainability in supply chain management in present time because of performance improvement and the external pressure, this study emphasizes to summarize the literature of sustainable global supply chain management that enable the researchers to see the overall picture of the stream and the gaps in literature can be identified.

The object of this study is to discover the yearly publication trends in the concerned area and to decide the cutting edge in SCM research by utilizing the exploration. Nevertheless, the outcomes of this study will contribute to future research. The organization of this study includes literature review, methodology, analysis, conclusion, and limitations for the future research.

\section{Literature review:}

Previous studies on sustainable supply chain management suggested that organizations need to pay critical attention to the social and environmental important principles to promote sustainability (Sarkis \& Zhu, 2018) Numerous studies, such as case studies, literature reviews, and empirical studies, suggest that various triple bottom line approaches must be integrated with the supply chain network.

\subsection{Concept of Sustainability in supply chain management and Global Context:}

The involvement of different players in value-creating activities to encourage the development of relationships are important for competing in the market with the change of environment is said as the supply chain management (Greenhalgh, 2001). This is important to integrate the social and environment practices into the supply chain network to compete in the market (Rao \& Holt, 2005) Different authors have defined sustainable supply chain over the period of time. (Svensson, 2007) defined sustainable supply chain in a very simple manner that is still valid in present time that focus only on the economic, social and environmental aspects. Alternatively, (Carter \& Rogers, 2008) discussed the integration of internal management practices with those three dimensions. (Seuring \& Müller, 2008) explained specifically about the information, capital and resources additionally they discussed about cooperation as well.

The Sustainability of supply chain management is when all three dimensions i.e. environmental, social and economic are considered and taken into account (Ciliberti et al., 2008). When social aspect is missing and only economic and environmental aspects are taken into account then it is eco-efficiency or green supply chain (Rossi et al., 2013) and (Pagell \& Wu, 2009). Sustainable supply chain management is the extended form of the green supply chain which is more complex (Ahi \& Searcy, 2013). 


\begin{tabular}{|c|c|}
\hline Sou & Sustainable supply chain management definitions \\
\hline $\begin{array}{l}\text { (Svensson, 2007) p. } \\
264\end{array}$ & $\begin{array}{l}\text { Sustainable supply chain management is a broader vision, which } \\
\text { highlight the social, economic and environmental sides of an } \\
\text { organizational practices. }\end{array}$ \\
\hline $\begin{array}{l}\text { (Carter \& Rogers, } \\
\text { 2008) } \\
\text { p. } 368\end{array}$ & $\begin{array}{l}\text { Transparent, strategic integration and organizational achievements in } \\
\text { environmental, social and economic goals with coordination and } \\
\text { systematic integration in organizational internal processes in order to } \\
\text { improve the long-term performance for organization itself and for its } \\
\text { supply chain network. }\end{array}$ \\
\hline $\begin{array}{l}\text { (Seuring \& Müller, } \\
2008) \\
\text { p. } 1700\end{array}$ & $\begin{array}{l}\text { The management of information, capital flows and resources as well } \\
\text { as cooperation of organizations in supply chain network while taking } \\
\text { goals related to economic, social and environmental all three } \\
\text { dimensions into account that are derived from different stakeholders' } \\
\text { requirements. }\end{array}$ \\
\hline $\begin{array}{l}\text { (Pagell \& Wu, 2009) p. } \\
38\end{array}$ & $\begin{array}{l}\text { Sustainable supply chain management is the one that focus on the } \\
\text { traditional approach of making profits along with that it focuses on } \\
\text { new extended concept of performance which specifically includes } \\
\text { natural and social dimensions. Sustainable supply chain is that which } \\
\text { perform well in all three dimensions of triple bottom line i.e } \\
\text { environment, social and economic by integrating its internal practices } \\
\text { to achieve the supply chain goal of sustainability and creating a true } \\
\text { supply chain sustainable. }\end{array}$ \\
\hline (Ahi \& Searcy, 2013) & $\begin{array}{l}\text { Through a voluntary integration of environment, social and economic } \\
\text { consideration creating a coordinated supply chains with inter- } \\
\text { organizational business systems that are designed to manage the } \\
\text { information, capital and material flow in production, distribution and } \\
\text { procurement along supply chain to meet the requirements of } \\
\text { stakeholders and improve the resilience, profitability and } \\
\text { competitiveness over long term as well as short term. }\end{array}$ \\
\hline $\begin{array}{l}\text { (Hassini et al., 2012) p. } \\
70\end{array}$ & $\begin{array}{l}\text { Managing the supply chain operations, funds, resources and } \\
\text { information in order to increase the profitability at same time reducing } \\
\text { the negative impact on environment and maximizing the wellbeing of } \\
\text { society. }\end{array}$ \\
\hline
\end{tabular}

Table-1 Authors' sources

Supply chain in present time plays an important role in global markets, so it requires an assessment and comprehension of underlying relations among participants (Reefke \& Sundaram, 2017). Resultantly organizations that are having operations globally need to respond as well recover from potential threats from global environment (Closs et al., 2011). Hence overall supply chain is moved to complex scenario that not only focus on the profitability but as well as the goals of sustainably of the environment (Liu et al., 2017).

Alternatively, in SSCM the interest among academia, managers and researchers is increasing (Köksal et al., 2017), and practices in industry are becoming trend for achieving sustainable 
development (Moktadir et al., 2018). Consequently, this need of improving performance and achieving sustainability have encouraged the supply chain sustainability that encompasses three dimensions to consider in operations (social, environmental and economic).

Around a decade ago, management of sustainable supply chain was combined by researchers to define SSCM (Ansari \& Qureshi, 2015), to overcome the challenges and meeting out the objectives tools and techniques used. Earliest in the literature it focuses on issues related to environment with topics like ecological products, green design and green supply chain ( $\mathrm{Yu} \&$ Tseng, 2014). Literature reviews later are suggesting different dimensions and definitions of SSCM (BeskeJanssen et al., 2015; Varsei, 2016), three dimensions specifically economic, social and environmental, and cooperation, collaboration and coordination among them along the supply chain networks (Ahi \& Searcy, 2013; Carter \& Rogers, 2008; Wolf, 2011).

Supply chain management plays an important role in achieving sustainability, where criteria for social, economic and environmental dimensions must be satisfied. It can also be seen in literature that supply chain management has advanced and is considered as an important thing to achieve organizational sustainable development (Reefke \& Sundaram, 2017), but still literature is suggesting that incorporation of sustainability in supply chain for business direction is limited (Gold \& Schleper, 2017).

Above all discussion regarding definitions, dimensions and gradual penetration of sustainability into supply chain network has revealed that still there is a need and research gap specially in the context of global supply chain to summarize the literature at a single place for researchers, academia and managers to get proper understanding of substantial development concept in Global Supply Chain context.

\section{Methodology:}

Li \& Cavusgil (1995) have suggested three ways to understand the state of knowledge in any stream of research, first one includes the Delphi method in which exports of the field are the surveyed, second one the meta-analysis in which the only the empirical studies related to any topic are gathered and then statically tested, third approach is the content analysis or in other words the quantitative or qualitative studies related any field are systematically analyzed. In this study I am using the third one approach that is the content analysis and by doing so expecting to find out the gaps in research area. Content analysis is divided majorly in three steps first is the analysis of the articles, defining the content with in each category and third on is the finding out the research gaps in literature (Ibrahim et al., 2015). 


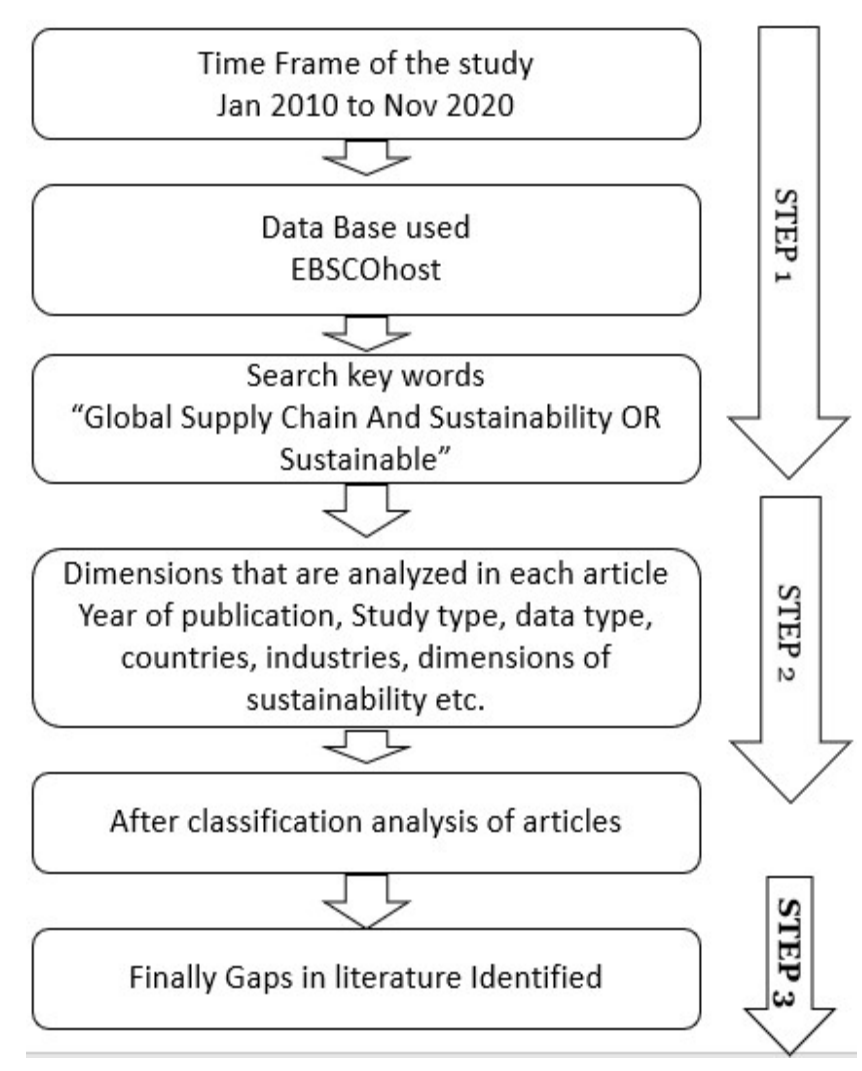

Figure-1 Content Analysis (SLR) steps of the study

Figure-1 shows brief steps used in content analysis in this paper. The articles used for analysis are within the time frame of January 2010 to November 2020, the reason of choosing this time frame is; I try to find out the recent trends in the field. Second data base used for searching the articles is EBSO host, Global supply chain related work is majorly published in the data bases of Taylor \& Francis, Science Direct, Emerald, Wiley and Inderscience, these data based are used by(Ibrahim et al., 2015) as a data sources in a same kind of study related to Global supply chain management. However, for sustainability the major data bases are Elsevier, MDPI and Springer this is shown by the (Sánchez-Flores et al., 2020) in a systematic literature conducted on sustainability. These allsuggested data bases related to work of global supply chain and sustainability are included in EBSO host.

For key word search, "global supply chain and sustainability OR sustainable" phrase is searched in the data base. For global supply chain related literature (Ibrahim et al., 2015) have used the phrase Global Supply chain only to find out the relevant articles whereas (Sánchez et al., 2020) in their study used the terms sustainable or sustainability to find out the articles related to sustainability literature. Hence, I have used the phrase "global supply chain and sustainability OR sustainable".

The search was limited to only academic journals and got 217 articles in total. After this by using excel formulas the articles were filtered that have used sustainability or sustainable along with global supply chain management at least in one of the tittles, keywords or abstract, in this way I got 119 articles. Then after this I have studied the abstract of these 119 articles, there were articles 
which have used the sustainability or sustainable term for other purposes such as sustainable competitive advantage in the same way the global word was used for some other meanings as well so these articles were not relevant to our study so I excluded them and along with that there were literature reviews too in the 119 articles that were also excluded in this way final sample was left that were 58 articles. 52 articles are included in this review, 6 articles copy I could not find.

After finalizing the sample of the study dimensions are finalized that are used for analyzing each article that include year of publications, methodology of research, data collection type, unit of analysis, industry, country in which data is being collected, respondents' types, theory that is used in the study, dimensions of the sustainability and finally the purpose of study whether it was to test the already existing theory or building up new theory.

Finally, after calculations with the help of charts and numbers, it is analyzed where less attention is being paid in the stream and gaps in literature will be identified.

\section{Results:}

The purpose of this study is to examine the patterns of publications in literature of sustainable global supply chain management. It is observed that since 2010 the interest in this field is increasing in resultantly the number of publications in each year is increasing, that shows that this field is growing fast. In figure-2 it can be seen that the yearly number of publications, which is showing that for year 2010 and 2011 within our sample there is no such study found, where as in year 2017, 2018 and 2020 highest number of papers published.

\section{NUMBER OF PAPERS PUBLISHED YEARLY}

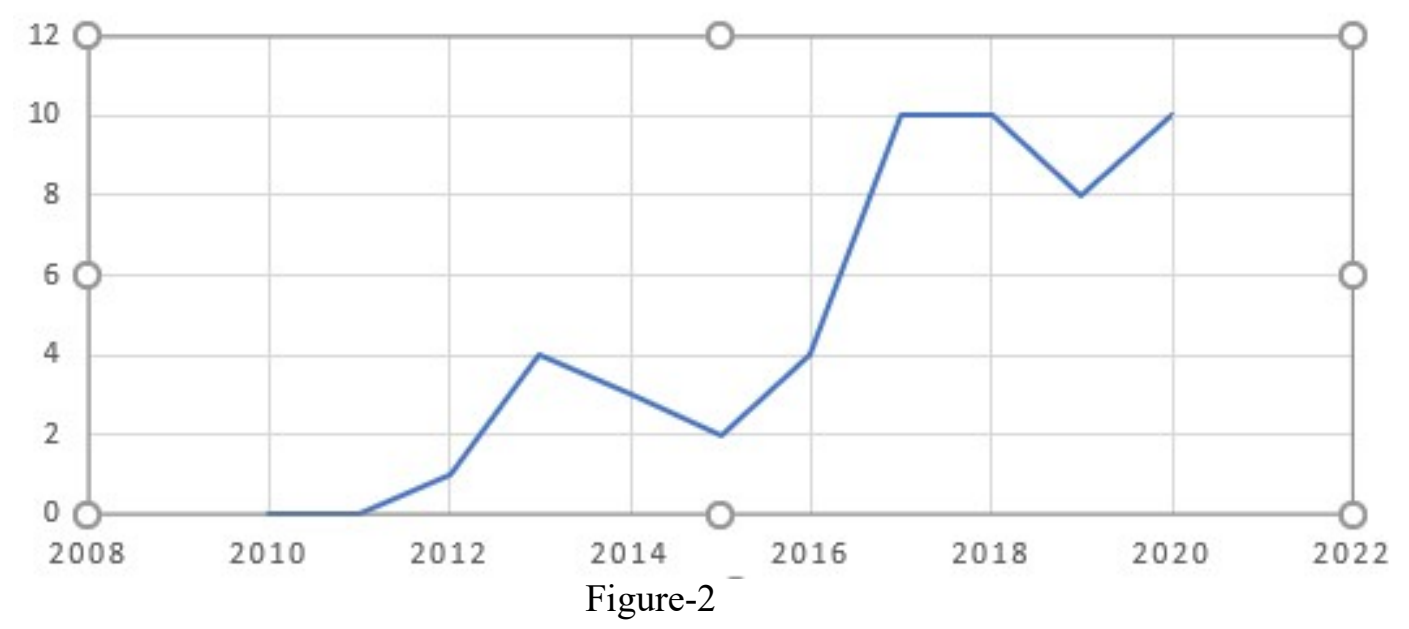

If we see the methodology of published papers, it is quite surprising that very few studies are only quantitative, whereas qualitative and the studies that use both methods are greater in number 27 and 22 respectively. Figure-3 shows the pie chart for methodology. 


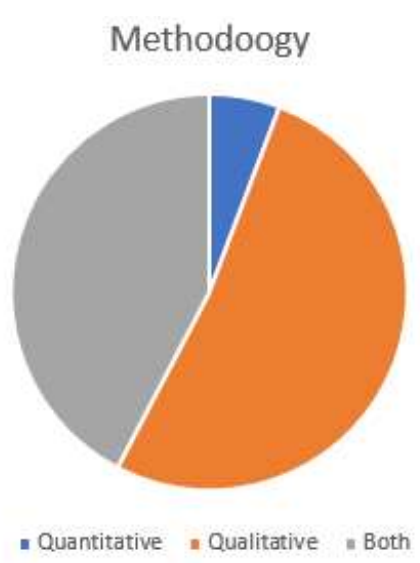

Figure-3

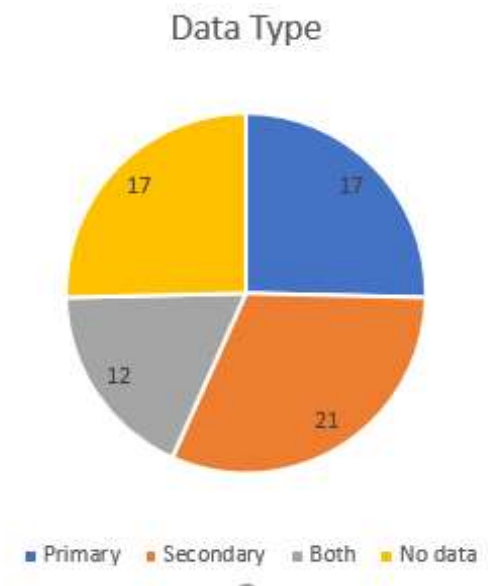

Figure-4

The data type is more or less same in numbers we can see in figure-4 that secondary data is used in most of the studies, there are 17 studies with primary and 17 studies with even no data. Only 12 studies are using both types of the data.

Mostly the studies have used organizations or firms as unit of analysis, around 3 studies have used unit of analysis as individual and 3 studies have used industry as a unit of analysis. 4 studies have used project as unit of analysis trade associations and managerial decisions are also used as a unit of analysis in only one study each. Figure-5 shows the pie chart for unit of analysis.

\section{Unit of Analysis}
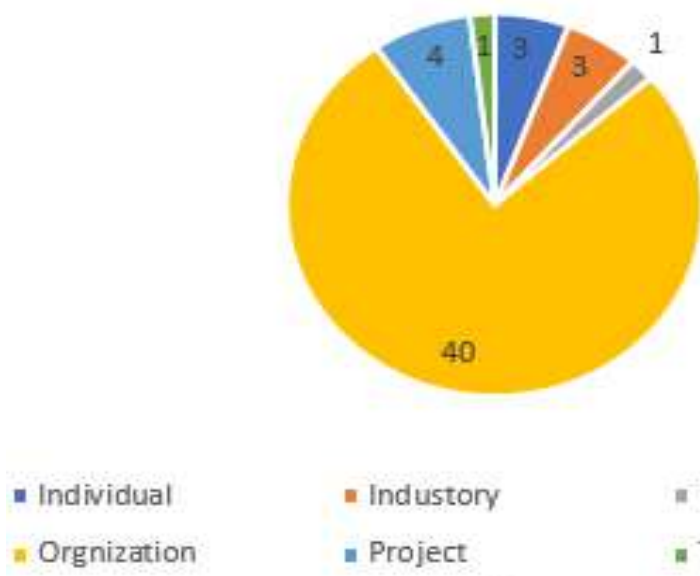

$$
\begin{aligned}
& \text { - Ind ustory } \\
& \text { - Project }
\end{aligned}
$$$$
\text { " Managerial Decission }
$$$$
\text { - Trade associations }
$$

Figure-5

There are around 21 unique industries in which data is collected. Around 20 studies have not given the data collection industry. Clothing and agriculture industries are used most for data collection around 4, 5 respectively studies have collected data from them. Further figure-6 shows the complete picture. 


\section{Data collection Industry}

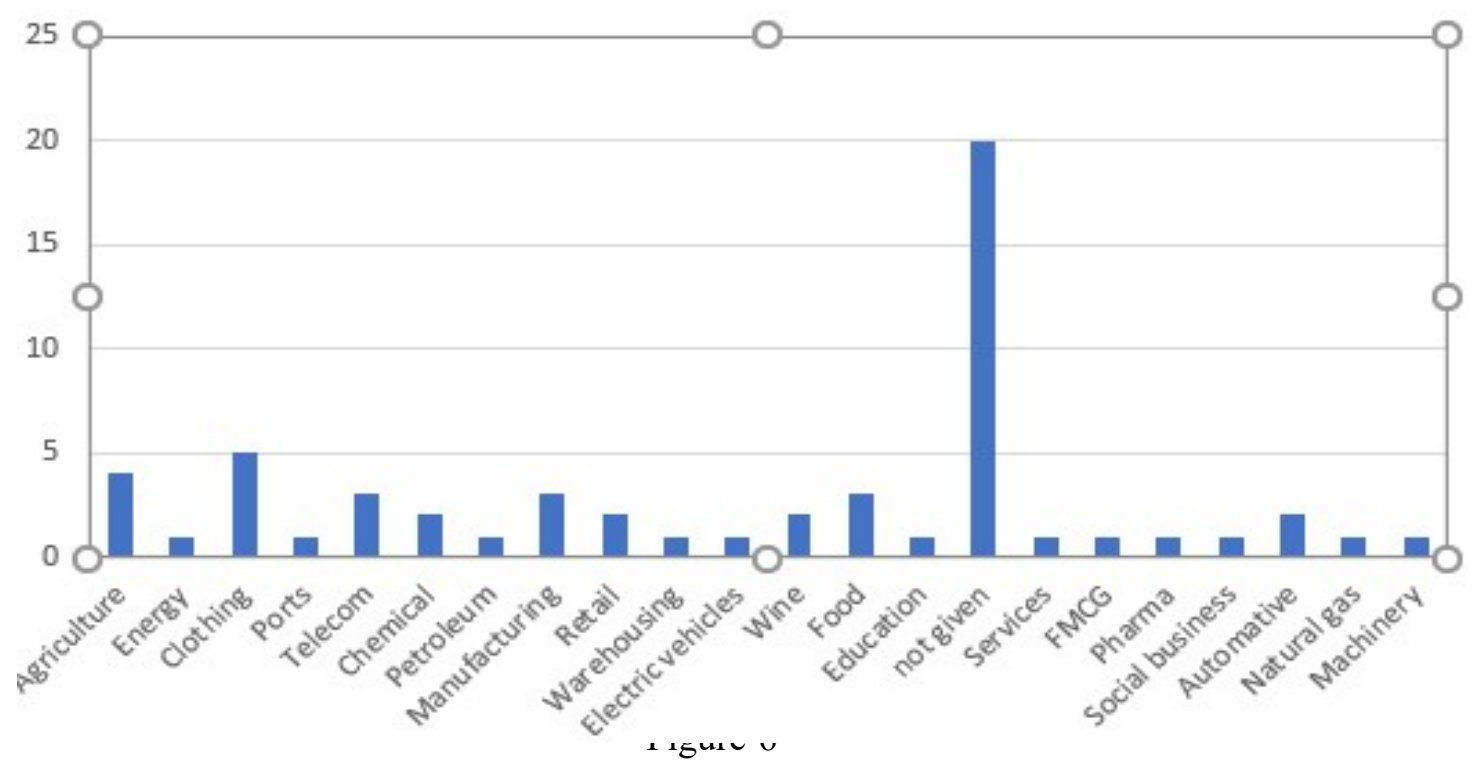

Taking about data collecting countries of the studies in our sample, figure-7 shows that highest number of studies collected that data from USA thereafter in China, Europe and India. Furthermore, the data is collected from Latin America, Germany, Bangladesh, Hong Kong, UK, Australia, France, South Korea, Brazil, Sweden, Russia, Vietnam, Haiti, Canada and Italy as well. Most of the studies either have not showed the data collection countries or they have not collected the data, there are around 24 studies in such group of studies.

\section{Data Collection Countries}

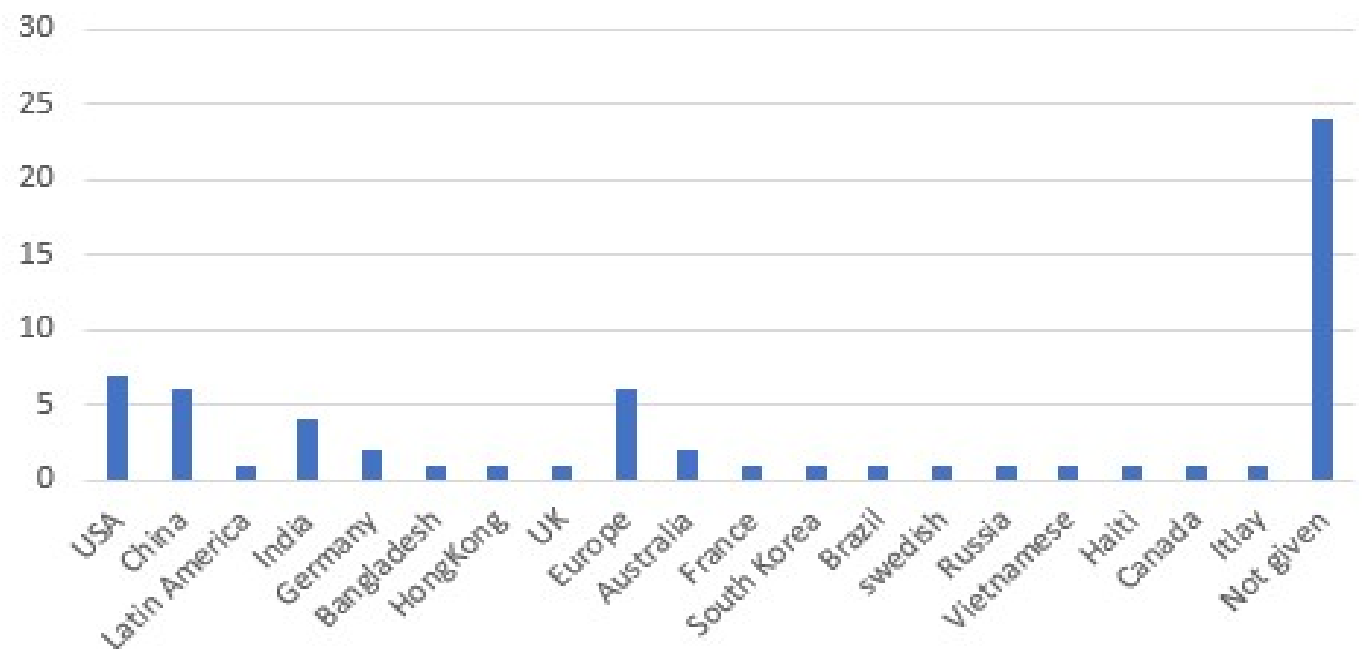

Figure-7

Around 39 studies have not shown the type of respondents form that they have collected the data. Managers and executives of the organizations are persons from whom data is collected largely. Then Experts, CEOs, Chief Purchasing officers and students are also used in studies as a source of data collection. Further figure8 shows the complete scenario. 


\section{Respondent Types}

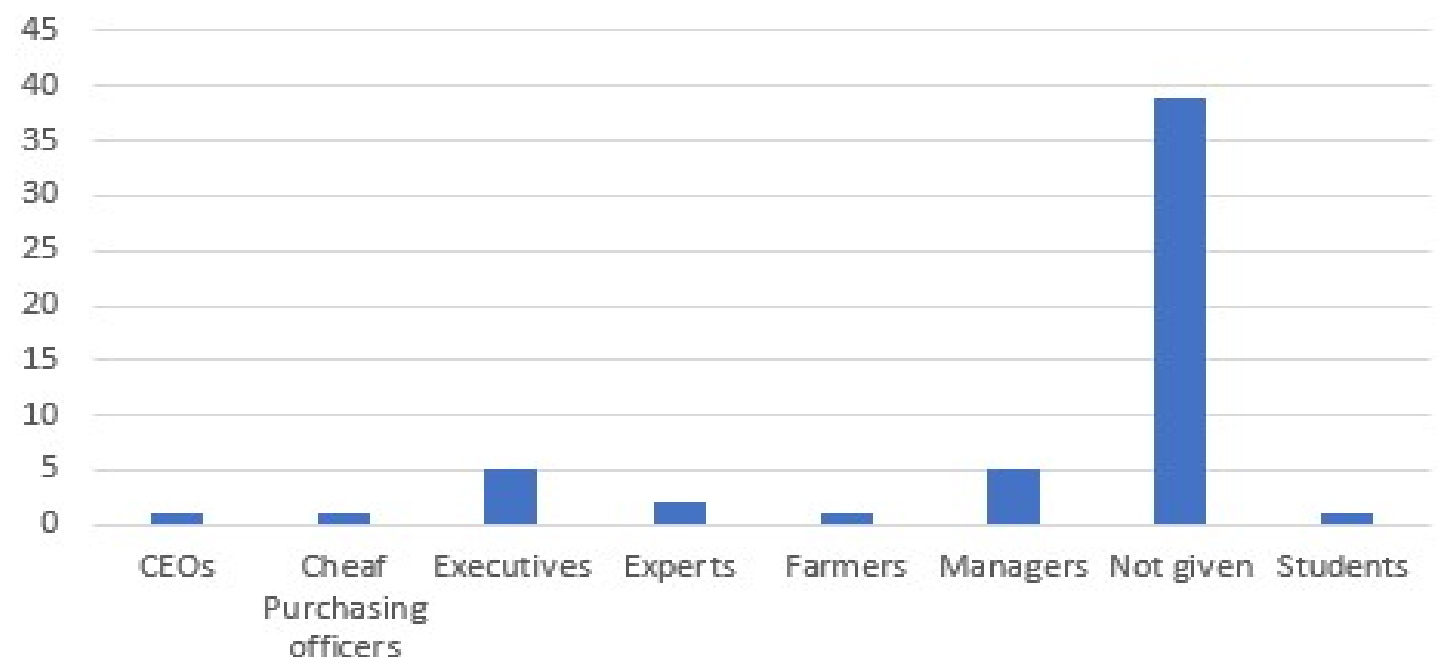

Figure-8

If we see the different theories used in the field, figure-9 shows us the complete picture. Most of the studies have not specified that what kind of theories are used in the studies. Where Institutional theory is used in two studies. Other theories that are used in the studies are conventional production theory, Transaction cost theory and multi attribute utility theory, circular economic model, resource-based view and path dependency theory.

\section{Theories Used}

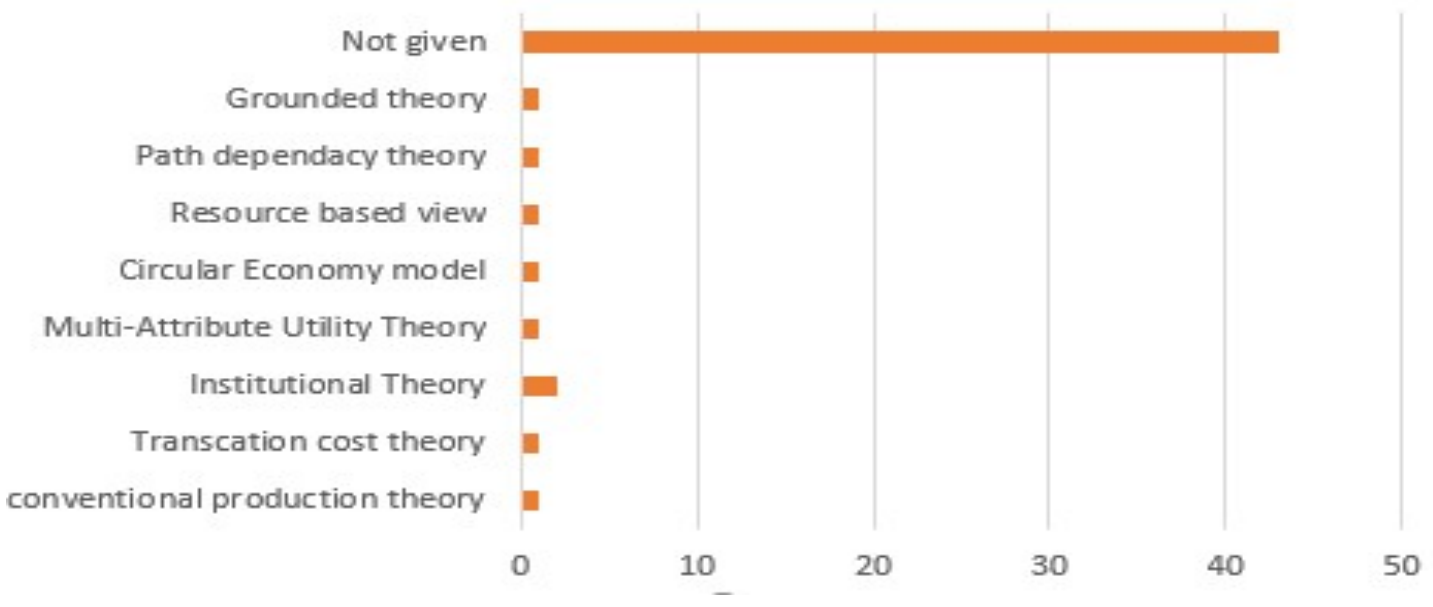

Figure-9

Figure-10 shows the dimensions of sustainability that studies are have used. It shows that environmental dimension of the sustainability is used by most studies. After that the social dimension of sustainability is also used in a lot of studies. Economic dimeson is used by 16 studies. Quality, Operational, Political and 
Financial dimension are also used as dimensions of sustainability in the studies. There are around 17 studies that have not specify what dimensions of sustainability they are using in the studies.

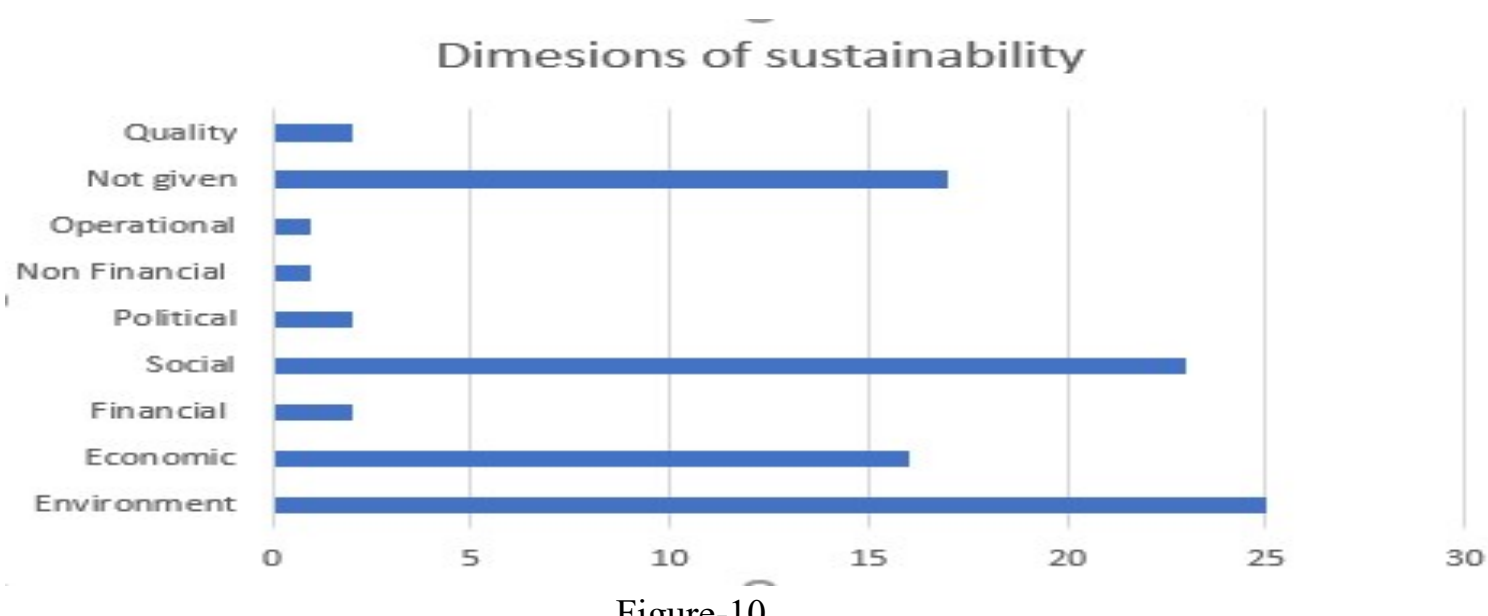

Figure-10

In figure-11 the pie chart shows the purpose of the studies specifically it is showing the number of studies that are used for theory building, verification or the elaboration. Around 44 studies are used for theory building, 4 studies are used for theory verification, and one study is used for both theory building and the theory verification. There are three studies that are used for theory elaboration.

\section{Theory Building or Varificaton}

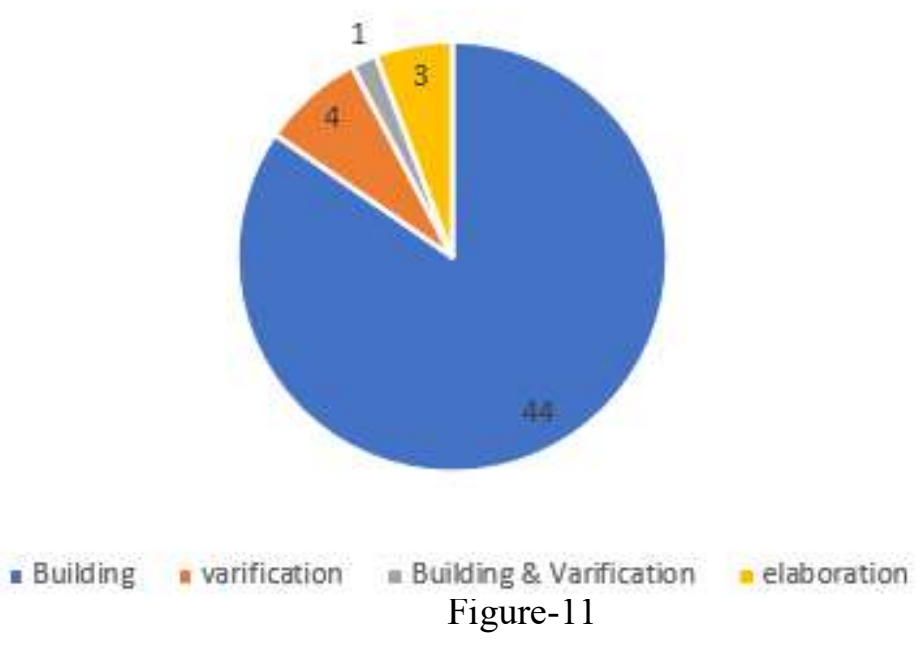

\section{Analysis:}

Sustainability in supply chain management is a new and growing field from last two decades a lot of attention is being paid to the sustainability in supply chain management field. The literature in sustainable supply chain management is also suggesting that, various highly cited articles that are defining the sustainable supply chain management we saw in literature part of this study that are since year 2007. In our study the publication trends in sustainable global supply chain management 
are showing this as well. We found that in our study that articles are increasingly published after year 2012 in sustainable global supply chain management. It means there are avenues for new researchers to explore this emerging field. Taking about the already existing systematic literature reviews in sustainable global supply chain management, we have not found any so far however literature reviews on sustainable supply chain management are available.

As the field is new and emerging this is visible from methodologies of the conducted studies as well, mostly studies are conducted that are qualitative and a very few studies are only quantitative. There are good number of studies which have conducted both qualitative and quantitative studies at same time. Studies in sustainable global supply chain network are mostly based on the case studies in which they have took various cases and analyzed them with the help of quantitative models and then they took and numerical example to justify the case due to this there are many studies which have conducted both methodologies. However, few Quantitative studies that are conducted are based on the secondary data.

Analyzing the tends of data collection types; mostly studies that have shown no data are the case studies that lies in the domain of the qualitative studies or these are those studies which are using the mathematic models and they are based on the numerical examples. Taking about the primary and secondary data types so there is no much differences in number of studies which use these types.

In Sustainable Global supply chain stream mostly, studies have used firm or organizations as unit of analysis, however it is visible that there is very less work done at individual level, trade associating, industry levels and even at the project levels. These can be the opportunities for the researcher to explore the field at these levels. As Sustainable supply chain can be analyzed at these unit of analysis as well.

There is not any specific industry where data is collected largely, as we saw results shows that various industries are used to test the results. Specifically, industries that are generating waste for the environment such as energy sector, petroleum and automotive sectors are the opportunities for the researchers to test the results.

The data collection countries patterns are showing that sustainable global supply chain related studies have majorly collected the data from the developed world countries such as US and Europe. Where emerging countries are are also being paid attention such as China and India. Very little attention is being paid to the developing world countries, so for the researchers here are opportunities too to explore the area in developing countries because developing countries in present time are also the part of global supply chain network, we can take example of Pakistan as well, Like Pakistan's sport industry is linked with Global supply chain network.

Respondents' type's results are showing that majorly data is collected from the internal management of organizations. However, the customers of such brands that are in global supply chain can also be a good source of data collection and can provide less biased results, so here the researchers there is a potential opportunity to explore the area in that side as well. A part from that other opportunities can be to collect the data from other stake holder which include the investors or the government agencies.

As literature suggested that for sustainable supply chain management it is important to link triple bottom approach with the supply chain network, here we can see clearly that in Global context 
sustainable supply chain management studies have used that concept in most of the studies which includes that environmental, social and economic sustainability. However, we can see that studies are using other dimensions to which is suggesting that sustainability is not only based on these dimensions but there can be other things too (see the results part). One more thing that is observed during the analysis of articles is that, studies are using the dimensions separately as well. For example, few studies have used only economic, environmental or even social dimensions.

There is not any specific theory that is majorly used in the studies as we saw in results part various studies are used in different articles. This shows that sustainable Global supply chain management is a broad stream where researchers can fit other theories as well like we saw transactional cost theory was used in a study. While looking at the results part the researcher has an opportunity to frame the work in other theories such as Resource dependency theory, network theory and dynamic capabilities as well; that are not used earlier.

Surprisingly more than $50 \%$ of studies are showing that they are used for theory building, from this is it also clear that the field is still emerging that why researchers are finding out new insights in the area. Few studies are used for theory elaboration as well, elaboration is just they have introduced some new concepts in the existing or already done work and they have mentioned in the contribution that they are elaborating the existing theories. For researchers here is an opportunity to test these theories because theory testing is done by very few papers in the area.

\section{Conclusion:}

Since past two decades great attention is being paid to the sustainability by firms. Internal and external pressures to the firms majorly drive the awareness for sustainability. Sustainability construct is multidimensional that is enlarging the concept of economic bottom line. For improving the present and future of organizations it is important to integrate the sustainability developmental goals with the supply chain management. Sustainable global supply chain is an important research stream this review presents a summary of the stream. In this study I used the content analysis methodology for literature review that is also known as systematic literature review.

In our study the publication trends in sustainable global supply chain management are showing this is an emerging stream. Mostly studies that are conducted they are qualitative and a very few studies are only quantitative. Primary and secondary both data collection methods are used in the area. Developed and emerging countries are used mostly for the data collection purpose. Respondents' types results are showing that majorly data is collected from the internal management of organizations. Sustainability dimensions including environmental, social and economic sustainability are widely used. There is no any specific theory that is majorly used in the articles various theories are used by various researchers. Mostly studies are used for theory building in the area that is also suggesting that this field is new and emerging.

Summing up the whole discussion it is clear that the field global sustainable supply chain management is new and emerging field and there is a lot of potential for researchers in the area to explore. 


\section{Research gap and Future Research}

Very few studies are conducted in the area that are quantitative and based on empirical data so there is potential opportunity for researchers to conduct the quantitative studies and test and verify the results of already developed literature. Taking about unit of analysis very less work done at individual level, trade associating, industry levels and even at the project levels, these can be the opportunities for the researcher to explore the field at those levels. Industries that are generating waste for the environment such as energy sector, petroleum and automotive sectors are the opportunities for the researchers to test the results. Very little attention is being paid to the developing world countries, so for the researchers here are opportunities too to explore the area in developing countries.

In literature of Sustainable global supply chain management various dimensions of sustainability are used by researchers, there is need for a clear concept of sustainability, so a separate study can be conducted that explores that true essence of sustainability in global supply chain context.

\section{Limitations}

The limitations of this study are due to time and resource constraints, I could not include the complete time frame for the studies to analyze and secondly If I have included other data bases in this study then I might have founded few important studies, that may be are missing currently in this study.

\section{References:}

Ahi, P., \& Searcy, C. (2013). A comparative literature analysis of definitions for green and sustainable supply chain management. Journal of Cleaner Production, 52, 329-341.

Ansari, Z. N., \& Qureshi, M. N. (2015). Sustainability in supply chain management: An overview. IUP Journal of Supply Chain Management, 12(2).

Beske-Janssen, P., Johnson, M. P., \& Schaltegger, S. (2015). 20 years of performance measurement in sustainable supply chain management-what has been achieved? Supply Chain Management: An International Journal.

Carter, C. R., \& Rogers, D. S. (2008). A framework of sustainable supply chain management: moving toward new theory. International Journal of Physical Distribution \& Logistics Management.

Christopher, M. (2005). Supply chain management. Creare valore con la logistica. Pearson Italia Spa. 
Ciliberti, F., Pontrandolfo, P., \& Scozzi, B. (2008). Investigating corporate social responsibility in supply chains: a SME perspective. Journal of Cleaner Production, 16(15), 1579-1588.

Closs, D. J., Speier, C., \& Meacham, N. (2011). Sustainability to support end-to-end value chains: the role of supply chain management. Journal of the Academy of Marketing Science, 39(1), $101-116$.

CONCEPTION, O. N. S. (2013). МЕХАНІЗМ ВИМІРЮВАННЯ РЕЗУЛЬТАТИВНОСТІ МАРКЕТИНГОВОЇ ВЗАЕМОДІЇ ПІДПРИЕМСТВ НА ОСНОВІ КОНЦЕПЦІЇ СИНЕРГІЗМУ.

Donald S, S. (2009). Green Management Matters Only if it Yieds More Green: An Economic/Strategic Perspective. Academy of Management Perspectives, 23(3), 5-16.

Elkington, J. (1997). Cannibals with forks. The Triple Bottom Line of 21st Century, 73.

Esfahbodi, A., Zhang, Y., Watson, G., \& Zhang, T. (2017). Governance pressures and performance outcomes of sustainable supply chain management-An empirical analysis of UK manufacturing industry. Journal of Cleaner Production, 155, 66-78.

German manufacturing industry. Journal of Business Ethics, 102(2), 221-235.

Gold, S., Seuring, S., \& Beske, P. (2010). Sustainable supply chain management and interorganizational resources: a literature review. Corporate Social Responsibility and Environmental Management, 17(4), 230-245.

Golinelli, G. M., \& Volpe, L. (2012). Consonanza, valore, sostenibilità: verso l'impresa sostenibile. Cedam.

Gopal, P. R. C., \& Thakkar, J. (2016). Sustainable supply chain practices: an empirical investigation on Indian automobile industry. Production Planning \& Control, 27(1), 49-64.

Greenhalgh, T. (2001). Computer assisted learning in undergraduate medical education. Bmj, $322(7277), 40-44$.

Haghighi, S. M., Torabi, S. A., \& Ghasemi, R. (2016). An integrated approach for performance evaluation in sustainable supply chain networks (with a case study). Journal of Cleaner Production, 137, 579-597.

Hassini, E., Surti, C., \& Searcy, C. (2012). A literature review and a case study of sustainable supply chains with a focus on metrics. International Journal of Production Economics, $140(1), 69-82$.

Hult, G. T. M., Ketchen, D. J., \& Arrfelt, M. (2007). Strategic supply chain management: Improving performance through a culture of competitiveness and knowledge development. Strategic Management Journal, 28(10), 1035-1052. 
Ibrahim, H. W., Zailani, S., \& Tan, K. C. (2015). A content analysis of global supply chain research. Benchmarking: An International Journal.

Köksal, D., Strähle, J., Müller, M., \& Freise, M. (2017). Social sustainable supply chain management in the textile and apparel industry-A literature review. Sustainability, 9(1), 100.

Li, T., \& Cavusgil, S. T. (1995). A classification and assessment of research streams in international marketing. International Business Review, 4(3), 251-277.

Liu, W., Bai, E., Liu, L., \& Wei, W. (2017). A framework of sustainable service supply chain management: A literature review and research agenda. Sustainability, 9(3), 421.

Moktadir, M. A., Ali, S. M., Rajesh, R., \& Paul, S. K. (2018). Modeling the interrelationships among barriers to sustainable supply chain management in leather industry. Journal of Cleaner Production, 181, 631-651.

Pagell, M., \& Wu, Z. (2009). Building a more complete theory of sustainable supply chain management using case studies of 10 exemplars. Journal of Supply Chain Management, 45(2), 37-56.

Rao, P., \& Holt, D. (2005). Do green supply chains lead to competitiveness and economic performance? International Journal of Operations \& Production Management.

Reefke, H., \& Sundaram, D. (2017). Key themes and research opportunities in sustainable supply chain management-identification and evaluation. Omega, 66, 195-211.

Rossi, S., Colicchia, C., Cozzolino, A., \& Christopher, M. (2013). The logistics service providers in eco-efficiency innovation: an empirical study. Supply Chain Management: An International Journal.

Sánchez-Flores, R. B., Cruz-Sotelo, S. E., Ojeda-Benitez, S., \& Ramírez-Barreto, M. (2020). Sustainable Supply Chain Management-A Literature Review on Emerging Economies. Sustainability, 12(17), 6972.

Seuring, S., \& Müller, M. (2008). From a literature review to a conceptual framework for sustainable supply chain management. Journal of Cleaner Production, 16(15), 1699-1710.

Svensson, G. (2007). Aspects of sustainable supply chain management (SSCM): conceptual framework and empirical example. Supply Chain Management: An International Journal.

Tonelli, F., Evans, S., \& Taticchi, P. (2013). Industrial sustainability: challenges, perspectives, actions. International Journal of Business Innovation and Research, 7(2), 143-163. 
Tseng, M.-L., Islam, M. S., Karia, N., Fauzi, F. A., \& Afrin, S. (2019). A literature review on green supply chain management: Trends and future challenges. Resources, Conservation and Recycling, 141, 145-162.

Varsei, M. (2016). Sustainable supply chain management: A brief literature review. The Journal of Developing Areas, 50(6), 411-419.

Winter, M., \& Knemeyer, A. M. (2013). Exploring the integration of sustainability and supply chain management: Current state and opportunities for future inquiry. International Journal of Physical Distribution \& Logistics Management.

Wolf, J. (2011). Sustainable supply chain management integration: a qualitative analysis of the Gold, S., \& Schleper, M. C. (2017). A pathway towards true sustainability: A recognition foundation of sustainable supply chain management. European Management Journal, 35(4), 425-429.

Wolf, J. (2014). The relationship between sustainable supply chain management, stakeholder pressure and corporate sustainability performance. Journal of Business Ethics, 119(3), 317328.

Yu, V. F., \& Tseng, L.-C. (2014). Measuring social compliance performance in the global sustainable supply chain: an AHP approach. Journal of Information and Optimization Sciences, 35(1), 47-72. 